\title{
COMPARATIVE GEOCHEMICAL STUDY OF THE TRIASSIC TRACHYANDESITES OF GLYKOMILIA AND ALKALI BASALTS FROM THE KOZIAKAS OPHIOLITE MÉLANGE (W. THESSALY): IMPLICATIONS FOR THEIR ORIGIN
}

\author{
Pomonis P., Tsikouras V. and Hatzipanagiotou K. \\ Section of Earth Mater als, Department of Geology, University of Patras, 265 00, Patras, \\ PPomonis@upatras.gr,.V.Tsikouras@upatras.gr,K.Hatzipanagiotou@upatras.gr
}

\begin{abstract}
The Triassic Glykomilia trachyandesites of the Koziakas mountain range (western Thessaly) are parts of the oldest volcanic series in continental central Greece. Rock fragments and blocks of pillowed alkali basalts, which are dispersed into the Koziakas ophiolite mélange, display similar subparallel chondrite-normelized trace and rare earth element patterns to the trachyandesites, suggesting cogenetic origin. However, the Glykomilia trachyandesites are more differentiated than the Koziakas alkali basalts, which display a different petrogenetic evolution from the basalts occurring in the Koziakas Ophiolite Unit. REE patterns and discrimination diagram plots reveal significant similarities to Triassic volcanic rocks from the Hellenides, suggesting also a VAB signature for the Glykomilia trachyandesites and a WPB affinity for the alkali basalts. Partial melting of a LILEenriched hydrous mantle under spreading conditions is suggested to give rise to Glykomilia trachyandesites. This partial melting episode was probably induced by the uplift of an OIB-type mantle plume, which subsequently produced the WPB alkali basalts of the Koziakas ophiolite mélange. The close association $c^{f}$ both the Glykomilia trachyandesites and the Koziakas alkali basalts with cherts lead to the hypothesis of eruption in a deep rift basin.
\end{abstract}

\section{INTRODUCTION}

In Greece, the oldest volcanic rocks associated with the Alpine orogenesis are of Palaeozoic to Early Mesozoic age. Hercynian (c. $300 \mathrm{Ma}$ ) subduction of Palaeotethys at an Andean-type margin (Finger \& Streyrer, 1990) was followed by Late Carboniferous, Permian and Triassic continental rifting of northeastern Gondwana, eventually leading to the creation of a mosaic of late Triassic to Jurassic small Red Sed-type ocean basins. The main rifting event took place in early to midTriassic times (Mountrakis et al., 1983; Robertson et al., 1991). Upper Scythian and Lower Anisian submarine lavas are usually associated with red limestones and cherts. Volcanic activity in places continued to the late Triassic (Pe-Piper, 1998).

The petrographic and geochemical data reported so far on the Triassic volcanic rocks from different outcrops of both external (Gavrovo-Tripolis and Pindos Units) and intermediate (Western Thessaly, Parnassos, Maliac and Eastern Greece Units) zones of Hellenides, indicate a wide compositional spectrum with rocks ranging from calc-alkaline to transitional alkaline and alkaline (e.g., Ardaens, 1978; Ferrière, 1982; Pe-Piper, 1982, 1983; Pe-Piper and Panagos, 1989; Pe-Piper and Mavronichi, 1990; Magganas et al., 1997; Capedri et al., 1997).

The Triassic volcanic rocks of the Koziakas mountain range (western Thessaly) are parts of the oldest volcanic series, associated with the Alpine orogenesis, in continental central Greece. In this study we attempt a geochemical comparison between Triassic trachyandesites found at the northern part of the Koziakas range and alkali basalts, found into the ophiolitic mélange of the Koziakas ophiolite. Our aim is to investigate their petrogenetic evolutions and the tectonic regime of their origin. 


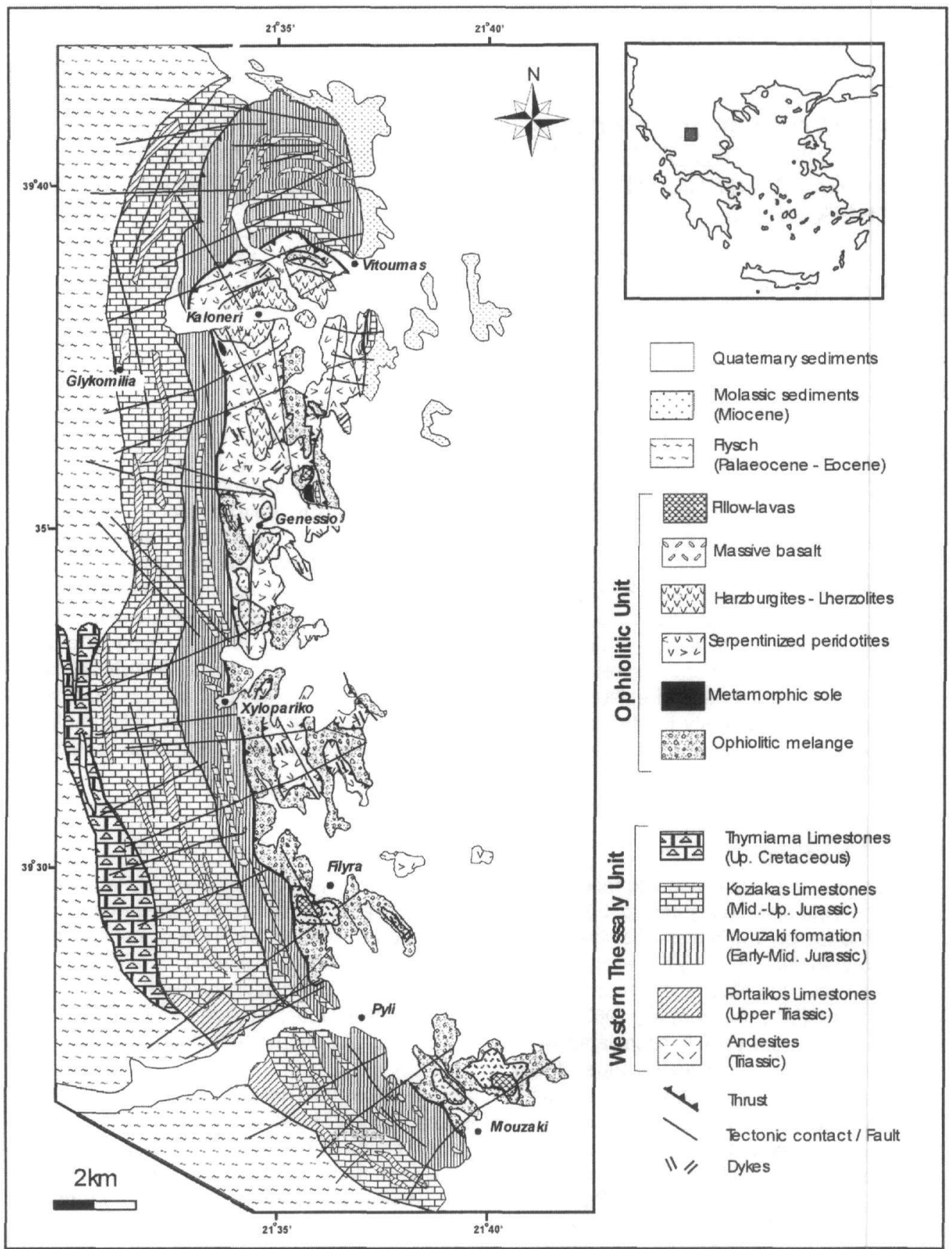

Figure 1. Geological map of the Koziakas ophiolite complex.

\section{FIELD OCCURRENCE}

The Koziakas ophiolite belongs to the Western Thessaly Unit - W.T.U. (Papanikolaou \& Sideris, 1979), a series of sedimentary and volcanic rocks of Upper Triassic - Eocene age. Extensive field- 
work in the ophiolitic complex of Koziakas focused on the distribution and mode of development of the ophiolitic rocks and $\mathrm{r}$ roduced a detailed geological map (Fig. 1).

The basement of the Koziakas ophiolite is represented by Alpine-type sedimentary rocks of the W.T.U., which occurs in the western part of the Koziakas mountain range. The Portaikos limestones of Upper Triassic age, comprises the lower member of the W.T.U. These rocks are overlain by the Mouzaki formation, which consists of medium-bedded sequences of cherts, siltstones and oolithic limestones of Lower - Middle Jurassic age. The Koziakas limestone formation is composed of oolithic limestones of Middle-Upper Jurassic age. It is tectonically overlain by the Mouzaki formation and locally underlain the Thymiama limestones of Upper Cretaceous age (indicated by the occurrence of microfossils). Finally, both the Koziakas and the Thymiama limestones are thrusted over the upper part of the W:U, consisting of Palaeocene-Eocene flysch, which is transitional to the Pindos flysch (Papanikolaou and Sideris, 1979; Lekkas, 1991).

The Koziakas ophiolitic complex is an uncompleted ophiolite unit with an ophiolitic mélange at its base. The ophiolite mélange is thrusted over the W.T.U. while it is also in thrust contact with the overlying ophiolitic unit. It comprises a chaotic, multicoloured mixture of rock-fragments of variable lithology, shape and size in the form of tectonic blocks. These blocks include serpentinites, peridotites, gabbros, dolerites, pillow-lavas, amphibolites, radiolarites, limestones, argillitic schists and sandstones. Small outcrops of sub-ophiolitic metamorphic rocks are thrusted over the ophiolite mélange. They are in tectonic contact with the overlying ophiolitic unit consisting a metamorphic sole. The lower parts of the dismembered ophiolite unit consists of serpentinites, serpentinized peridotites (harzburgites and Iherzolites) intruded by gabbroic, rodingitized gabbro and plagiogranitic veins up to $0.5 \mathrm{~m}$ width (not shown on the map). Its upper parts include small outcrops of olivine gabbro, dolerites and pillow lavas interlayered with Mn-rich radiolarites (Pomonis, 2003).

The Koziakas alkali basalts were detected into the ophiolitic mélange (Fig.1) only, as dispersed fragments, locally associated with red limestones fragments of Upper Triassic age (Portaikos limestones) and radiolarites. In cases, there are fragments of pillow alkali basalts associated with radiolarites, the later following all their surface anomalies. The alkali basalts are usually purplish with amygdules, or blue-grey when fresh. Few samples display amygdules.

The Triassic trachya ndesites occur in in the NW part of the Koziakas mountain range, near Glykomilia village (Fig.1). They form small lava flows, about 50m in thickness concordantly associated with Norian conodonts bearing red limestones (Portaikos limestones) and radiolarites (Magganas et al., 1997). The colour of these volcanics is light brown to grey-beige, while in fractured areas, due to oxidation, it is dark brown to black. They show porphyritic structure with well-observed phenocrysts of feldspars and pyroxenes, with a size of $2-3 \mathrm{~mm}$ and rarely up to $1 \mathrm{~cm}$.

\section{PETROGRAPHY}

The Koziakas alkali basalts display a range of textures from aphyric and variolitic to plagioclaseporphyritic. When texture is porphyritic, the proportion of phenocrysts to groundmass is variableSubhedral laths of plagioclase and interstitial clinopyroxene, are settled in an intergranular to intersertal groundmass with microlites of plagioclase and clinopyroxene. The plagioclase and clinopyroxene crystals present variable alteration or replacement signs by secondary minerals. Locally feldspar crystals are almost completely altered to calcite. Fe-Ti oxides are the opaque phases present and they have a strong association with the altered crystals. Secondary minerals due to lowgrade ocean metamorphism found: quartz, albite, epidote, chlorite, pumpellyite, calcite, hematite, titanite and actinolite. Some samples display calcite-chlorite-filled amygdules. Carbonate veins cutting all mineral phases have also been seen.

The Glykomilia trachyandesites are unusually fresh with porphyritic texture ( 40 vol. $\%$ phenocrysts). Local accumulation of feldspars and pyroxenes phenocrysts creates a glomeroporphyric structure. Their groundmass is hypocrystalline, composed mainly of brownish glass. The feldspars are weakly altered to smectite and celadonite, and consist mainly of plagioclase, whereas in smaller amounts K-feldspars occur. The celadonite, however, might well represent altered pyroxene inclusions within the feldspars. Twinning and zoning are common in all feldspars. Other alteration products are: calcite, albite, pumpellyite, Fe-oxides, quartz, chlorite and rarely epidote and 
white mica. Locally, chlorite replaces partly or totally phenocrysts of pyroxenes and feldspars. Veinlets of chlorite, calcite and quartz, cross cut the rock.

\section{ANALYTICAL TECHNIQUES}

Whole-rock major element analyses were performed using a JY24 Sequential Spectrometer (ICP-AES), while Si was determined by X-ray fluorescence, using a Spectro Analytical X-Lab 2000 XRF spectrometer. Detection limits for most elements were less than $0.005 \mathrm{wt} . \%$ in the sample and analytical errors characteristically varied from $2 \%$ to $5 \%$, depending on the element determined and its concentration.

Trace and Rare Earth Elements (REE) were determined on totally digested samples by inductively coupled plasma-r.ass spectrometry (ICP-MS) using a VG Elemental Plasma Quad II, following techniques described in Bailey et al. (1993) and Lewis et al. (1997). Detection limits were generally sub ppb in solution, equivalent to sub ppm levels in rock samples, taking into account dilution factors. Precision varied from 5 to $10 \%$, depending on the element determined and its concentration.

All analyses were performed at the University of Bristol, Department of Earth Sciences.

\section{GEOCHEMISTRY}

Major-, trace- and rare-earth element analyses of representative samples from the Koziakas alkali basalts and trachyandesites are reported in Table 1. Loss on ignition (L.O.I.), which is generally considered as an index of alteration, is rather low in the analyzed samples (with few exceptions mainly in alkali basalts with about 3-6.9). However, studies of low-temperature, seawaterdominated alteration of rocks have shown that the mobility of several elements is affected by seawater interaction (e.g., Seyfried \& Mottl, 1982; Alt et al., 1986; Lecuyer et al., 1990). Besides, the alteration seems to have affected the potassium concentration of Glykomilia volcanic rocks, which shows, in comparison with many other elements, a wider range from $3.94 \%$ wt. up to $5.33 \%$ wt. Thus, in order to constrain on the petrogenesis of these lavas, we based our investigation mostly on the immobile elements.

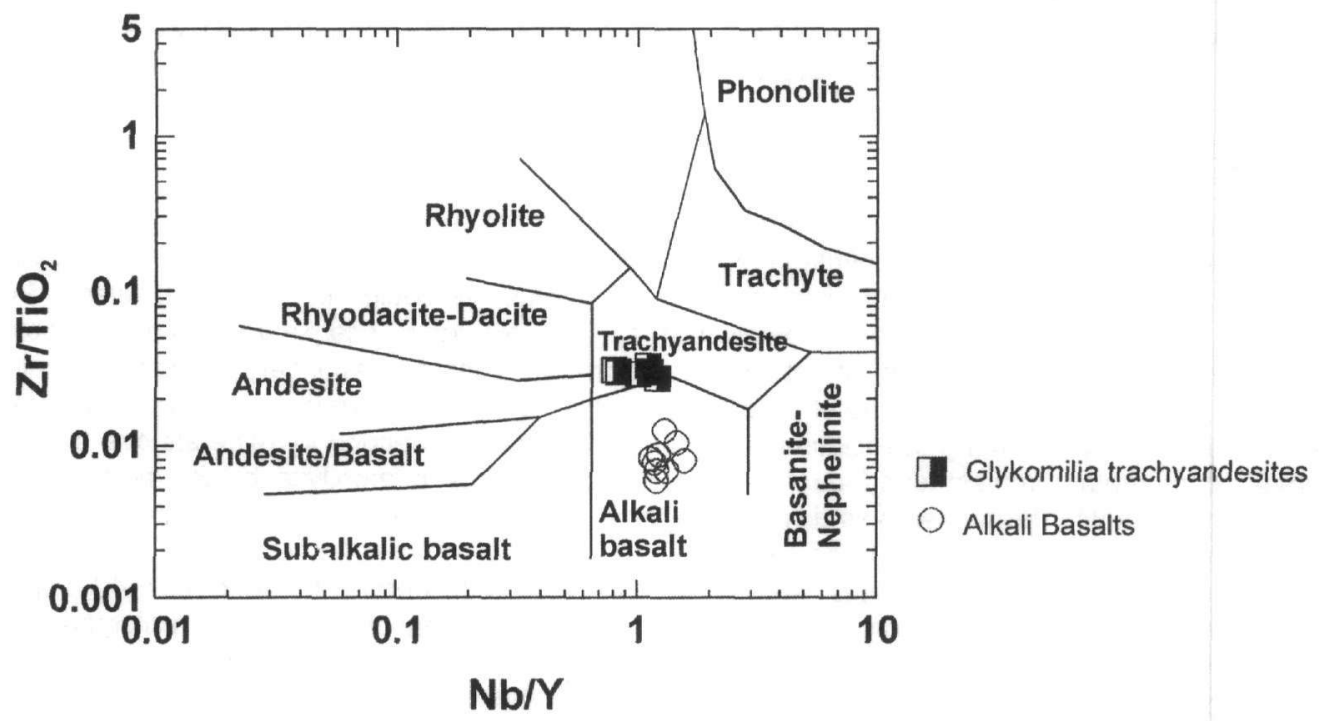

Figure 2. $\mathrm{Zr} / \mathrm{TiO}_{2}$ vs $\mathrm{Nb} / \mathrm{Y}$ plot of Winchester and Floyd (1977) for the Koziakas alkali basalts and Glykomilia trachyandesites. 
Table 1. Geochemical analyses of representative trachyandesites and alkali basalts

from the Koziakas mountain range (- :below detection limit, *:not determined).

Major Elements (\%wt)

\begin{tabular}{|c|c|c|c|c|c|c|c|c|}
\hline \multicolumn{5}{|c|}{ Alkali Basalts } & \multicolumn{4}{|c|}{ Trachyandesites } \\
\hline & $F 17$ & $F 38 \mathrm{~b}$ & $A 176$ & $A 177$ & GL7 & GL20 & GL21 & GL23 \\
\hline $\mathrm{SiO}_{2}$ & 45.22 & 46.53 & 46.83 & 47.36 & 69.51 & 65.82 & 66.68 & 65.34 \\
\hline $\mathrm{TiO}_{2}$ & 1.30 & 1.57 & 1.57 & 1.41 & 0.68 & 0.69 & 0.61 & 0.70 \\
\hline $\mathrm{Al}_{2} \mathrm{O}_{3}$ & 16.97 & 17.27 & 15.34 & 16.83 & 13.64 & 14.40 & 14.07 & 14.76 \\
\hline $\mathrm{Fe}_{2} \mathrm{O}_{3}{ }^{\mathrm{t}}$ & 8.32 & 7.94 & 8.52 & 8.97 & 3.30 & 4.18 & 4.59 & 4.44 \\
\hline $\mathrm{MnO}$ & 0.14 & 0.12 & 0.14 & 0.22 & 0.05 & 0.08 & 0.17 & 0.10 \\
\hline MgO & 4.90 & 5.90 & 5.91 & 4.06 & 1.24 & 1.92 & 2.05 & 2.01 \\
\hline $\mathrm{CaO}$ & 11.16 & 10.46 & 11.16 & 11.87 & 2.22 & 3.05 & 2.52 & 1.42 \\
\hline $\mathrm{Na}_{2} \mathrm{O}$ & 4.26 & 4.23 & 5.03 & 5.44 & 2.88 & 3.98 & 4.21 & 3.81 \\
\hline $\mathrm{K}_{2} \mathrm{O}$ & 0.21 & 0.14 & 0.12 & 0.33 & 4.46 & 3.94 & 3.98 & 5.33 \\
\hline $\mathrm{P}_{2} \mathrm{O}_{5}$ & 0.21 & 0.27 & 0.30 & 0.24 & 0.13 & 0.27 & 0.24 & 0.26 \\
\hline LOI & 6.89 & 5.59 & 4.60 & 3.05 & 1.96 & 1.00 & 0.90 & 1.70 \\
\hline Total & 99.58 & 100.02 & 99.52 & 99.78 & 100.07 & 99.32 & 100.02 & 99.86 \\
\hline \multicolumn{9}{|c|}{ Trace Elements (ppm) } \\
\hline v & 267 & 252 & 360 & 276 & 81 & 116 & 107 & 113 \\
\hline $\mathrm{Cr}$ & 350 & 300 & 149 & 243 & 38 & 30 & 27 & 31 \\
\hline Co & 30 & 26 & - & 17 & * & * & * & * \\
\hline $\mathrm{Cu}$ & 66 & 75 & - & 39 & * & * & * & * \\
\hline $\mathbf{N i}$ & 138 & 125 & 231 & 135 & 25 & 32 & 21 & 27 \\
\hline Zn & 84 & 60 & - & 72 & * & * & * & * \\
\hline $\mathbf{R b}$ & 4 & - & 2 & - & 114 & 113 & 128 & 129 \\
\hline $\mathrm{Sr}$ & 224 & 164 & 159 & 80 & 194 & 268 & 255 & 171 \\
\hline Y & 27 & 21 & 19 & 24 & 9 & 8 & 9 & 8 \\
\hline $\mathbf{Z r}$ & 96 & 104 & 116 & 121 & 187 & 205 & 196 & 199 \\
\hline $\mathrm{Nb}$ & 27 & 36 & 34 & 44 & 11 & 9 & 10 & 8 \\
\hline Ba & 50 & 54 & 40 & 26 & 595 & 544 & 681 & 702 \\
\hline Sc & 29 & 34 & 29 & 28 & 11 & 21 & 27 & 18 \\
\hline Hf & 3 & 3 & 3.2 & 3.2 & 5 & 5 & 4 & 5 \\
\hline Ta & 2 & 2 & 4.9 & 2.7 & 1 & 1 & 2 & 1 \\
\hline Th & 2.7 & 2 & 4.8 & 4.2 & 12 & 12 & 13 & 13 \\
\hline$\underline{U}$ & 0.8 & 1 & - & 1.1 & * & ${ }^{*}$ & * & * \\
\hline \multicolumn{9}{|c|}{ Rare Earth Elements (ppm) } \\
\hline La & 22 & 28 & 33 & 33 & 30 & 34 & 35 & 44 \\
\hline $\mathrm{Ce}$ & 41 & 53 & 33 & 60 & 63 & 66 & 66 & 58 \\
\hline Pr & 5 & 6 & 9 & 7 & 7 & 10 & 11 & 16 \\
\hline Nd & 20 & 23 & 24 & 25 & 26 & 29 & 27 & 41 \\
\hline $\mathrm{Sm}$ & 4.40 & 4.20 & 4.98 & 4.80 & 4.70 & 5.76 & 5.78 & 8.29 \\
\hline Eu & 1.30 & 1.37 & 1.47 & 1.40 & 1.00 & 1.14 & 1.10 & 1.73 \\
\hline Gd & 4.90 & 4.70 & 6.23 & 4.70 & 4.80 & 7.06 & 7.22 & 9.93 \\
\hline Tb & 0.80 & 0.70 & 0.65 & 0.80 & 0.60 & 0.66 & 0.63 & 0.86 \\
\hline Dy & 4.60 & 3.70 & 4.27 & 4.20 & 3.20 & 3.80 & 3.68 & 5.42 \\
\hline Ho & 0.90 & 0.70 & 0.73 & 0.80 & 0.70 & 0.71 & 0.70 & 0.89 \\
\hline $\mathrm{Er}$ & 2.90 & 2.40 & 2.14 & 2.50 & 2.20 & 2.11 & 1.89 & 2.71 \\
\hline $\mathrm{Tm}$ & 0.46 & 0.33 & 0.29 & 0.37 & 0.31 & 0.23 & 0.29 & 0.35 \\
\hline Yb & 2.80 & 2.00 & 1.87 & 2.30 & 1.90 & 1.92 & 2.16 & 2.62 \\
\hline Lu & 0.43 & 0.33 & 0.29 & 0.36 & 0.32 & 0.27 & 0.35 & 0.38 \\
\hline
\end{tabular}


According to $\mathrm{Zr} / \mathrm{TiO}_{2}$ vs. $\mathrm{Nb} / \mathrm{Y}$ diagram (Winchester \& Floyd, 1977, Fig.2), which uses immobile elements only, the analyzed volcanic rocks from Glykomilia plot in the field of trachyandesite, whereas the analyzed volcanic rocks from the Koziakas ophiolitic mélange are classified as alkali basalts. The alkali basalts display higher values in $\mathrm{TiO}_{2}, \mathrm{Al}_{2} \mathrm{O}_{3}, \mathrm{Fe}_{2} \mathrm{O}_{3}{ }^{\mathrm{t}}, \mathrm{MgO}, \mathrm{CaO}$ and $\mathrm{Na}_{2} \mathrm{O}$ and lower $\mathrm{SiO}_{2}$ and $\mathrm{K}_{2} \mathrm{O}$ values relative to trachyandesites. On the other hand, the high $\mathrm{Si}$ and $\mathrm{K}$ contents indicate a transitional alkaline geochemical character for the Glykomilia lavas.

The low $\mathrm{MgO} \mathrm{FeO}^{t}$ ratio $(0.38-0.48)$ of Glykomilia lavas, relative to alkali basalts $(0.41-0.88)$ indicates a more evolved geochemical character for the trachyandesites. Moreover, the trachyandesites display higher Th/La (0.29-0.40), Th/Yb(4.85-6.32), Th/Ta(7.56-19.67) and $\mathrm{La} / \mathrm{Nb}(2.73-5.46)$ incompatible element ratios relative to alkali basalts (Th/La:0.07-0.14, Th/Yb:0.96-2.57, Th/Ta:0.841.55, La/Nb:0.75-0.98).

Rare earth element natterns of both rock types normalized to chondrite, are plotted in Figure 3. In this figure the patterns of alkali basalts are represented for comparison by an envelope, which outlines their maximum and minimum normalized REE values. The Glykomilia trachyandesites characterized by a strong enrichment in LREE and slightly fractionated HREE ((Ce/Yb) N:5.35-3.79). Similar REE profiles present the Koziakas alkali basalts with slightly lower LREE values $\left((\mathrm{Ce} / \mathrm{Yb})_{\mathrm{N}}: 3.75-7.72\right)$ relative to trachyandesites. Moreover, both rock types display subparallel fractionated HREE $\left((\mathrm{Tb} / \mathrm{Yb})_{\mathrm{N}}: 1.37-1.83\right)$. The well pronounced negative $\mathrm{Eu}$ anomaly of Glykomilia trachyandesites indicates rather plagioclase separation.

\section{DISCUSSION}

As evidenced by the overall geochemical features, the petrogenetic evolution of Glykomilia trachyandesites is related with this of the alkali basalts from the Koziakas ophiolitic mélange. Their

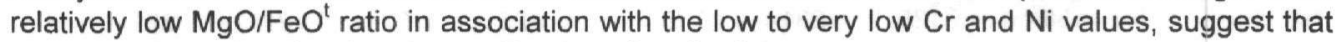
they were formed by fractional crystallization of mafic phases.

The high Th/La, Th/Yb, Th/Ta and La/Nb ratios of Glykomilia trachyandesites, which are higher than the Koziakas alkali basalts is an evidence that trachyandesites probably underwent significant chemical interaction with a continental crust, or a subducted slab activity is involved to their genesis. These ratios are hiçher than in mantle-derived magmas unaffected by crust interaction. Analogous geochemical signatures present the Triassic volcanic rocks from Vardoussia and Argolis (Capedri et al., 1997). On the other hand, the above incompatible element ratios are lower in the Koziakas alkali basalts $(<1)$ and analogous to those from basalts unaffected by crust contamination (Pearce, 1982). The absence of a "crustal signature" in the Koziakas alkali basalts is consistent with either emplacement onto an ocean floor, or intrusion through the continental crust via rapid ascent that prevented extensive differentiation and crustal contamination.

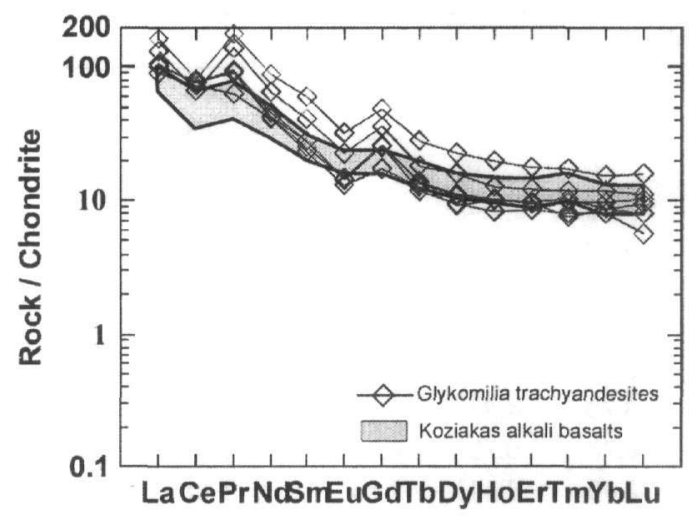

Figure 3. Chondrite-normalized REE diagram for the Glykomilia trachyandesites and Koziakas alkali basalts (normalized values after Nakamura et al., 1974). 
In the diagram Th/Yb vs Ta/Yb (modified from Menzies and Kyle, 1990, Fig.4), the analyzed samples of Glykomilia trachyandesites plot at high $\mathrm{Th} / \mathrm{Yb}$ values, in the field of rocks affected by crustal recycling or contamination, close to the Triassic volcanic rocks of Argolis and Othrys (Capedri et al., 1997). On the other hand, the Koziakas alkali basalts plot in the field of rocks with MORB and WPB affinities, which are unaffected by crust interaction, close to the alkali basalts of Avdella mélange (Pindos) and those of Evia (Capedri et al., 1997).

The alkali character of both studied volcanic rock-types is also consistent with the chondritenormalized patterns (Fig.5). In this diagram, the patterns of alkali basalts are represented for comparison by an envelope, which outlines their maximum and minimum chondrite-normalized values. The patterns of both Glykomilia trachyandesites and Koziakas alkali basalts are subparallel with several enrichments particularly for LIL elements, whereas the HFSE are fractionated. Moreover, the trachyandesites are slightly richer in LIL elements than alkali basalts and display strong negative $\mathrm{Nb}, \mathrm{P}, \mathrm{Ti}$ and $\mathrm{Y}$ anomalies. We note that $\mathrm{Nb}$ depleted basalts with high Th values call for a descending slab activity (Dercourt, 1980; Rocci et al., 1980; Pe-Piper and Panagos, 1989). The similar and subparallel chondrite-normalized trace and REE patterns of both rock types, in combination with the distinct HREE-fractionation (see Fig.3) suggest a common mantle-source origin.

In the Hf/3-Th-Ta discrimination diagram (Wood, 1980; Fig.6) the alkali basalts plot in the field of Within Plate Basalts (WPB), whereas the Glykomilia trachyandesites plot in the field of Volcanic Arc Basalts (VAB), suggesting again that a subduction related environment has been involved in their genesis. The WPB geochemical affinities of the alkali basalts are also consistent with their REE and trace element patterns, which are similar to Ocean Island Basalts (OIB). Alkali basalt with OIB-like trace element assemblages is known from the Avdella mélange (Jones and Robertson, 1991), interpreted by Robertson et al. (1990) as seamounts in the Pindos ocean.

Our geochemical data could lead to the hypothesis that the trachyandesitic extrusive rocks of Glykomilia probably derived by partial melting of a LILE-enriched hydrous mantle, under spreading conditions (Pe-Piper, 1998; Turner and Hawkersworth, 1995). The small volume of these rocks is consistent with such an origin rather than by subduction. Furthermore, several authors believe that there is only little independent regional evidence for subduction in the Triassic Pindos basin (Hynes, 1974; Bebien et al., 1980; Duncan, 1987; Robertson et al., 1990). However, isotope and geochemical features suggest that hydration of the mantle may has been taken place during an earlier Hercynian subduction (Pe-Piper 1998). This partial melting episode was probably induced by the uplift of an OIB-type

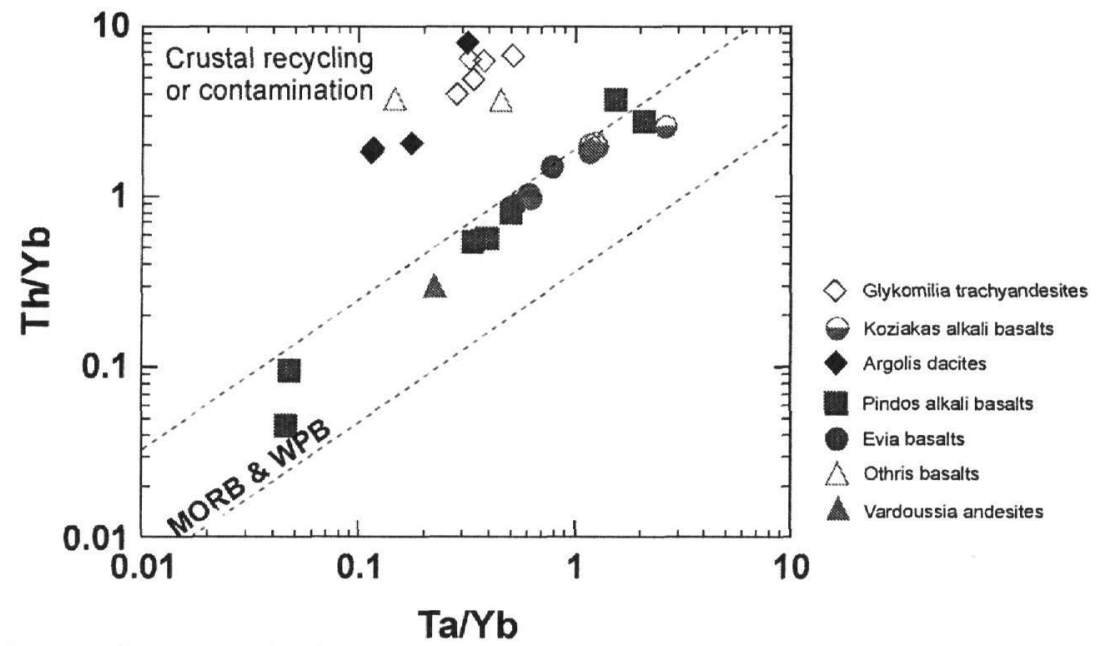

Figure 4. Th/Yb vs Ta/Yb (modified from Menzies and Kyle, 1990) for the Koziakas alkali basalts and Glykomilia trachyandesites, compared to other Triassic volcanic rocks from Greece and to Mid-Ocean ridge and Within plate volcanic rocks (diagonal dotted band of constant Th/ta ratio). 


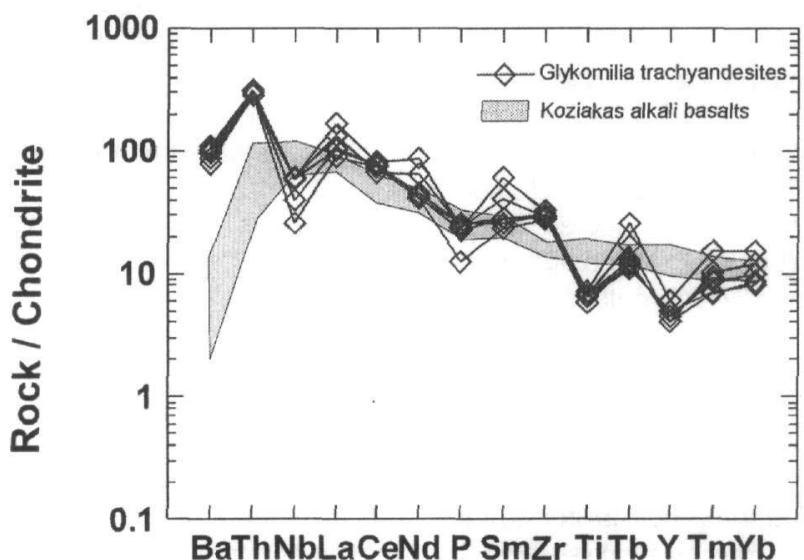

Figure 5. Chondrite-normalized trace-element diagram for the Glykomilia trachyandesites and Koziakas alkali basalts (normalized values after Thompson et al., 1984).

mantle plume, which subsequently gave rise to the WPB alkali basalts of the Koziakas ophiolite mélange.

The close association of both the Glykomilia trachyandesites and the Koziakas alkali basalts with cherts lead to the hypothesis of eruption in a deep rift basin. Since the Glykomilia trachyandesites contain a "crustal" component, this occurred during a relatively short transitional period between the ending of continental rifting and the opening of the Pindos ocean. The presence of pillow textures and the absence of any "crustal" signature in alkali basalts support their extrusion onto the floor of an already evolved ocean basin, hence the alkali basalts evolved after the trachyandesites. In such a case, to explain the less differentiated nature of the Koziakas alkali basalts, we suggest that mixing of a primitive magma, produced from melting of a subducted lithosphere, with the already differentiated magina is required.

A contemporary formation of the Glykomilia trachyandesites and Koziakas alkali basalts is an also plausible hypothesis. In this case, the absence of the "crustal" component from the chemistry of the Koziakas alkali basalts could be explained if they had risen rapidly to the surface. On the other hand a relatively slower rise of Glykomilia trachyandesites, which characterized by extensive fractional crystallization, accompanied by "crustal" contamination.

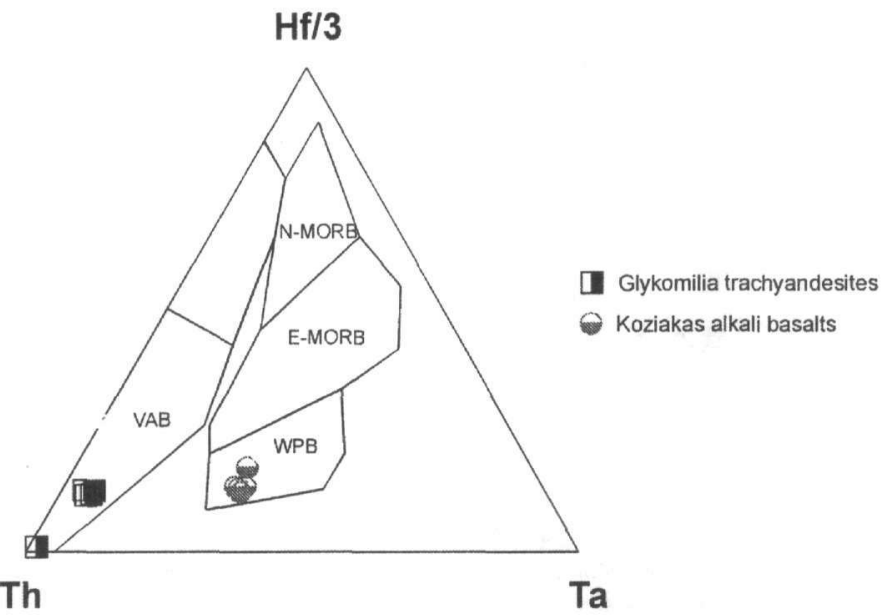

Figure 6. Hf/3-Th-Ta diagram (Wood, 1980) for the Glykomilia trachyandesites and Koziakas alkali basalts. 


\section{CONCLUSIONS}

The Triassic trachyandesite found at the northern part of the Koziakas range and the alkali basalts, located into the nphiolitic mélange of the Koziakas ophiolite display similar alkaline geochemical characteristics. Although, the Glykomilia trachyandesites are more differentiated than the Koziakas alkali basalts and they have been affected by "crustal" contamination.

Both rock-types display similar, subparallel chondrite-normalized trace and rare earth element patterns, suggesting cogenetic origin. They illustrate LILE-enrichments and HFSE-depletions, resulted by their alkaline character. REE patterns are subparallel, enriched in LREE and show distinct HREE-fractionation, suggesting a common mantle-source origin for the trachyandesites and the alkali basalts. Furthermore, REE patterns and discrimination diagram plots reveal significant similarities to Triassic volcanic rocks from the Hellenides, suggesting also an island-arc signature for the Glykomilia trachyandesi'es and a WPB affinity for the alkali basalts.

The geochemical data presented here indicate that the trachyandesitic extrusive rocks of Glykomilia were probably derived by partial melting of a LILE-enriched hydrous mantle, under spreading conditions in a deep rift basin. This partial melting episode was probably induced by the uplift of an OIB-type mantle plume, which subsequently gave rise to the WPB alkali basalts of the Koziakas ophiolite mélange. The presence of pillow textures and the absence of any "crustal" signature in alkali basalts support their extrusion onto the floor of an already evolved ocean basin, hence the alkali basalts possibly evolved after the trachyandesites. In opposite, a contemporary formation of the Glykomilia trachyandesites and the Koziakas alkali basalts could be explained if the latter had risen rapic'ly to the surface.

\section{ACKNOWLEDGEMENTS}

We would like to thank Prof. Dr. B.J. Wood and the researchers of the University of Bristol, Department of Earth Sciences, for their assistance in elaborating whole-rock analyses, under financial support of a TMR Programme. This study was supported through the Caratheodory Programme of the University of Patras.

\section{REFERENCES}

Alt, J.C., Honnorez, J., Laverne, C. and Emmermann, R., 1986. Hydrothermal alteration of a $1 \mathrm{Km}$ section through the upper oceanic crust, Deep Sea Drilling Project Hole 504B : mineralogy, chemistry and evolution of seawater-basalt interactions, J. Geoph. Res., 91, 309-335.

Ardaens, R., 1978. Géologie de la chaîne du Vardoussia, comparaison avec le massif du Koziakas (Grèce continentale), Thèse $3^{\text {rd }}$ cycle, Univ. Lille, 222pp.

Bailey, E.H., Kemp, A.J., and Ragnarsdottir, K.V., 1993. Determination of uranium and thorium in basalts and uranium in aqueous solution by Inductively Coupled Plasma Mass Spectrometry, J. Anal. Atomic Spectrom., $8,551-556$.

Bébien, J., Ohnenstetter, D., Ohnenstetter, M., and Vergely, D., 1980. Diversity of the Greek ophiolites: Birth of oceanic basins in transcurrent systems, Ofioliti, 2, 129-197.

Capedri, S., Toscani, L., Grandi, R., Venturelli, G., Papanikolaou, D. and Skarpelis, N.S., 1997. Triassic Volcanic Rocks of some Type-localities from the Hellenides, Chem. Erde, 57, 257-276.

Dercourt, J., 1980. Les zones externes de l' édifice hellenique. In: Géologie des pays européens, Dunod, Paris, 4. 361-371.

Duncan, A.R., 1987. The Karoo igneous province - a problem area for inferring tectonic setting from basalt geochemistry, J. Volc. Geoth. Res., 32, 13-34.

Ferrière, J., 1982. Paléogéographies et tectoniques superposées dans les Hellénides internes: les massifs de l'Othrys et de Pélion, Soc. Geol. Nord. Publ. 8, 970pp.

Finger, F. and Steyrer, H.P., 1990. I-type granitoids as indicators of a late Paleozoic convergent oceancontinent margin along the southern flank of the central European Variscan orogen, Geology, 18, 12071210.

Hynes, A., 1974. Igneous activity at the birth of an ocean basin in eastern Greece, Can. J. Earth Sci., 11, 842853.

Jones, G., and Robertson, A.H.F., 1991. Tectono-stratigraphy and evolution of the Mesozoic Pindos ophiolite and related units, northwestern Greece, J. Geol. Soc. London, 148, 267-288 
Lecuyer, C., Brouxel, M., and Albarede, F., 1990. Elemental fluxes during hydrothermal alteration of the Trinity ophiolite (California, USA) by seawater, Chem. Geol., 89, 87-115.

Lekkas, E.L., 1991. The presence of Western Thessaly Unit at Dafnospilia-Ktimeni area (S. Thessaly, Greece), Bull. Geol. Soc. Greece 25/1, 231-344.

Lewis, A.J., Palmer, M.R., Sturchio, N.C., and Kemp, A.J., 1997. The rare earth element geochemistry of acidsulphate and acid-sulphate-chloride geothermal systems from Yellowstone National Park, Wyoming, USA, Geochim. Cosmochim. Acta, 61, 695-706.

Magganas, A., Kyriakopoulos, K. and Lekkas, E., 1997. Early Alpine Rift Volcanism in Continental Greece: the Case of Glykomilia Area (Koziakas Mountain), Chem Erde, 57, 243-255.

Menzies, M.A., and Kyle, P.R., 1990. Continental volcanism: a crust-mantle probe. In: Continental Mantle, Menzies, M.A., (ed.), Oxford Science Publications, Oxford Monographs on Geology and Geophysics, Claredon Press, Oxford, 157-177.

Mountrakis, D., Sapountzis, E., Killias, A., Eleftheriadis, and C., Christofides, G., 1983. Palaeogeographic conditions in the western prlagonian margin in Greece during the initial rifting of the continental area, Can. J. Earth Sci., 20, 1673-1681.

Nakamura, N., 1974. Determination of REE, Ba, Fe, Mg, Na and $\mathrm{K}$ in carbonaceous and ordinary chondrites, Geochim. Cosmochim. Acta, 38, 757-775.

Papanikolaou, D., and Sideris, C., 1979. Sur la signification des zones «ultrapindique " et "béotienne " d'après la géologie de la région de Karditsa : l'unité de Thessalie Occidentale, Ecl. geol. He/v., 72/1, 251261.

Pearce, J.A., 1982. Trace element characteristics of lavas from destructive plate boundaries, In: Thorpe R.S. (ed.), Andesites. Wiley and Sons, 525-548.

Pe-Piper, G., 1982. Geochemistry, tectonic setting and metamorphism of mid-Triassic volcanic rocks of Greece, Tectonophysics, 85, 253-272.

Pe-Piper, G., 1983. Triassic shoshonites and andesites, Lakmon Mnt., western continental Greece. Differences in primary geochemistry and sheet silicate alteration products, Lithos, 16, 23-33.

Pe-Piper, G., 1998. The nature of Triassic extension-related magmatism in Greece: evidence from $\mathrm{Nd}$ and $\mathrm{Pb}$ isotope geochemistry, Geol. Mag., 135(3), 331-348.

Pe-Piper, G. and Mavronichi, M., 1990. Petrology, geochemistry and regional significance of the Triassic volcanic rocks of the W. Parnassos isopic zone of Greece, Ofioliti, 15-2, 269-285.

Pe-Piper, G. and Panagos, A., 1989. Geochemical characteristics of the Triassic volcanic rocks of Evia: petrogenetic and tectonic implications, Ofioliti, 14, 33-50.

Pomonis, P., 2003. The Koziakas Ophiolite: Geological study, Petrogenetic evolution, Geotectonic Interpretation, Ph.D. Thesis, Unis: of Patras, 328pp.

Robertson, A.H.F., Clift, P.D., Degnan, P.J., and Jones, G., 1990. Tectonic and sedimentary evolution of the Mesozoic-Tertiary Pindos ocean: Greece, In: Savascin, M. Y. and Eronat, A.H. (eds.), IESCA-1990 Proceedings, Ismir, 2, 253-263.

Robertson, A.H.F., Clift, P.D., Degnan, P.J., and Jones, G., 1991. Palaeogeographic, and palaeotectonic evolution of the Eastern Mediterranean Neotethys., Palaeogeography, Palaeoclimatology, Palaeoecology, 87, 289-343.

Rocci, G., Paroz, F., Bebien, J., Desmet, A., Lapierre, H., Ohnenstetter, D., Ohnenstetter, M., amd Parrot, J.F., 1980. The Mediterranean ophiolites and their related Mesozoic volcanosedimentary sequences. In: Panayiotou, A. (ed), Ophiolites, proc. Intern. Ophiolite Symp. Cyprus, 1979, 273-286.

Seyfried, W.E., and MottI, IM.J., 1982. Hydrothermal alteration of basalt by seawater under seawater-dominated conditions, Geochim. Cosmochim. Acta, 46, 985-1002.

Thompson, R.N., Morrison, M.A., Hendry, C.N., and Parry, S.J. 1984. A new assessment of the relative roles of crust and mantle in magma genesis: an elemental approach, Phil. Trans. Roy. Soc. Lon, ser. A, 310, 549590 .

Turner, S. and Hawkersworth, C., 1995. The nature of the sub-continental mantle: constaints from the majorelement composition of continental flood basalts, Chem. Geol., 120, 295-314.

Winchester, J.A., and Floyd, P.A., 1977. Geochemical discrimination of different magma series and their differentiation products using immobile elements, Chem. Geol., 20, 325-343.

Wood, D.A., 1980. The application of a Th-Hf-Ta diagram to problems of tectonomagmatic classification and to establishing the nature of crustal contamination of basaltic lavas of the British Tertiary volcanic province., Earth Planet. Sci. Lett., 50, 11-30. 